originalni

naučni

rad

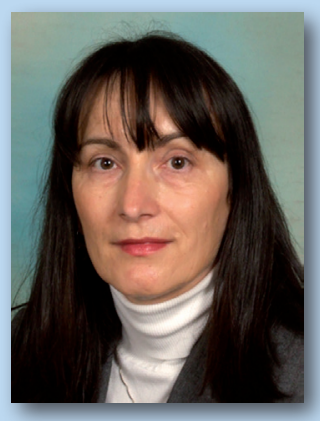

dr Danica Prošić

Master World d.o.o. danicaprosic@eunet.rs

\title{
Rezime
}

Kamatni svop je derivat koji se danas rutinski koristi u finansijskom sektoru u svetu. Nasuprot tome, svop tržište u Srbiji je svedeno samo na osnovne verzije kamatnih svopova i ograničeno većim korisnicima i pružaocima usluga na finansijskom tržištu. Srpske banke sporo uvode i promovišu kamatne svopove kao jedne od svojih usluga, što je vidljivo iz brojnih informacija o kamatnim svopovima i neinovativnih ponuda ovih instrumenata. Sa druge strane kompanije nisu u stanju da prepoznaju kamatne svopove kao instrument za zaštitu od negativnih efekata promena kamatnih stopa i načina za postizanje konkurentne prednosti u odnosu na ostale tržišne učesnike.

Jedna od prepreka za korišćenje svopova je nespremnost kompanija da se informišu, edukuju i upuste u nove transakcije. Obim sklopljenih svop transakcija ovisi o nivou razumevanja njegovih učesnika. Proširivanje znanja pomaže u premošćavanju jaza između teorije i prakse i podstiče na veću primenu kamatnih svopova u budućnosti.

Ključne reči: diskontovanje novčanih tokova, fer vrednost, kamatni rizik, kamatni svop, računovodstvo zaštite

JEL: E43, G23, M41 


\section{MECHANISM AND ACCOUNTING TREATMENT OF INTEREST RATE SWAP}

dr Danica Prošić

Master World d.o.o. danicaprosic@eunet.rs

\section{Summary}

Interest rate swap is a derivative which is today routinely used in the financial sector worldwide. As opposed to that, the swap market in Serbia is reduced to basic versions of interest rate swaps only, and is limited to the major users and providers of services in the financial market. Banks in Serbia have been introducing and promoting interest rate swaps as one of their services rather slowly, which can be deduced from various information on interest rate swaps and non-innovative offers of these instruments. On the other hand, companies are unable to recognize interest rate swaps as instruments of hedge against the negative effects of interest rate fluctuations, and a way to gain competitive edge in relation to other market participants.

One of the obstacles for using interest rate swaps is unwillingness of companies to get informed and educated, and to enter new transactions. The volume of conducted swap transactions depends on the level of understanding on the part of their participants. Expansion of knowledge helps bridge the gap between theory and practice, thereby encouraging a more intensive implementation of interest rate swaps in the future.

Keywords: cash flow discounting, fair value, interest rate risk, interest rate swap, hedge accounting 


\section{Uvod}

Neizvesno, a u poslednje vreme sve burnije finansijsko okruženje zahteva od banaka, kompanija i drugih ekonomskih subjekata veoma ozbiljan pristup u upravljanju kamatnim rizikom koji proizilazi iz ove vrste okruženja. U takvim uslovima, obavljanje transakcija na klasičan način ne obezbeđuje u dovoljnoj meri zaštitu od potencijalnog kamatnog rizika. To je dalo podsticaj finansijskoj teoriji i praksi za razvoj i uvođenje u svakodnevnu praksu raznih vrsta derivativnih instrumenata. Derivat koji se međutim, izdvaja je svop koji je već duže vreme u svetu prepoznat kao efikasan i nezaobilazan instrument za upravljanje kamatnim rizikom. S obzirom na brojne potencijalne koristi postao je osnovni alat za mnoge investitore, korporativne rizničare i menadžere banaka.

Svopovi su ovisni o kretanjima kamatnih stopa s obzirom na to da ova kretanja direktno utiču na efikasnost tržišta svopova (Glantz, Morton, 2003). Stoga, je neophodno dobro poznavanje prirode kamatnih stopa. Objašnjenja promena kamatnih stopa i njihovih uzroka uvek izazivaju kontroverze. Jedan od razloga je nedovoljna informisanost o faktorima koji utiču na promene kamatnih stopa. Drugi razlog je objektivna složenost procesa koji utiču na njihove promene. Zbog toga je i upućenim ekspertima ponekad nemoguće objasniti, a kamoli tačno predvideti, promene kamatnih stopa.

Trend smanjivanja kamatnih stopa na srpskom bankarskom tržištu prisutan je nekoliko godina unazad i za očekivati je da će se nastaviti s obzirom na povoljna kretanja na međunarodnim tržištima. Međutim, do izjednačavanja kamata u Srbiji i razvijenijim zemljama EU neće doći tako brzo. Osim prisutnog trenda slabe tražnje za kreditima u privatnom sektoru, kamatna stopa uglavnom je vezana uz očekivanja ekonomskih aktera, kako onih koji imaju viškove novca, tako i onih koji imaju potrebe za finansiranjem. Ipak, stanje $u$ srpskoj privredi ne ohrabruje ni jedne ni druge.

Kamatni svop je derivat sa kojim se najčešće trguje u svetu, tržište svopova je ogromno, procenjuje se $\mathrm{u}$ trilionima dolara širom sveta. Konkretno, tržištem kamatnih svopova dominiraju velike finansijske institucije kao što su banke i hedž fondovi. Osnovna uloga svop banaka je posredovanje ali one mogu da obavljaju i niz drugih važnih funkcija.

Svopovi su OTC proizvodi, koji se sklapaju i odvijaju izvan berze. Razumevanje OTC tržišta kamatnih svopova omogućuje dublje razumevanje tržišta kapitala koga u velikoj meri čini tržište obveznica, razumevanje načina na koji kompanije čije akcije posedujemo upravljaju kamatnim rizikom i načina na koji banke generišu veliki deo prihoda. Upotreba kamatnih svopova bankama i njihovim klijentima može omogućiti jeftinije finansiranje i zaštitu od negativnih efekata promena kamatnih stopa bez obzira da li su dužnici ili investitori novčanih sredstava (Cuthberston, 2001). Stoga, ogromna veličina tržišta svopova koji olakšavaju zaštitu od kamatnog rizika ne treba da iznenađuje.

Tendencija porasta korišćenja ovih kreacija finansijskog inženjeringa $u$ razvijenim zemljama obrazlaže se njihovom jednostavnom primenom, fleksibilnošću, niskim transakcionim troškovima kao i realnim mogućnostima da se kamatni rizik smanji ili neutrališe.

Cilj ovog rada je detaljnije upoznavanje sa pravilima korišćenja kamatnih svopova i njihovim računovodstvenim tretmanom. Teorija obrađena u ovom članku potkrepljena je praktičnim primerom kako bi se dobio što detaljniji uvid u ovu problematiku i izazove sa kojima se s tim u vezi susrećemo.

\section{Mehanizam funkcionisanja kamatnih svopova $u$ praksi}

U oblasti derivata, popularna forma svopa je kamatni svop kojim se razmenjuje jedan set kamatnih plaćanja za drugi. Postoji veliki broj različitih vrsta kamatnih svopova. Ipak, najveći broj svop transakcija odnosi se na veoma jednostavan proizvod poznat kao klasični (generic) ili plain vanilla svop u kom se razmenjuju plaćanja fiksne za plaćanja varijabilne kamatne stope na osnovu fiktivnog iznosa glavnice. Kamatni svop je serija terminskih ugovora o kamatnoj stopi - forward contracts on interest rates (Hull, 2007). U suštini, razmenjuju se samo neto kamatna plaćanja. To znači da onaj čiji je dug veći plaća razliku kamata suprotnoj strani.

Kamatni svop je dugoročni ugovor zaključen na period od tri meseca pa do petnaest godina a 


\section{Introduction}

The uncertain and recently ever more turbulent financial environment requires from banks, companies and other economic entities an extremely serious approach to the management of interest rate risk arising from such an environment. Under such circumstances, performing transactions in the traditional manner does not provide sufficient protection from the potential interest rate risk. This has encouraged financial theory and practice to develop and introduce all kinds of derivative instruments into the everyday business practice. However, a derivative which has singled out is swap, for quite some time recognized in the world as an efficient and unavoidable instrument for interest rate risk management. Given its numerous potential benefits, it has become the basic tool for many investors, corporate treasurers and bank managers.

Swaps are dependent on interest rate movements given that these movements directly affect the efficiency of the swap market (Glantz, Morton, 2003). Therefore, it is necessary to be well acquainted with the nature of interest rates. The explanations of interest rate fluctuations and their causes have always caused much controversy. One of the reasons is insufficient knowledge about the factors affecting the interest rate changes. Another reason is the objective complexity of the processes influencing their changes. This is why it is sometimes impossible, even for experienced experts, to explain, let alone exactly foresee, the changes in interest rates.

The trend of decreasing interest rates at the banking market of Serbia has been present for several years now, and it might be expected to continue given the favorable movements at the international markets. However, quite some time will pass before the interest rates in Serbia match those in the developed countries of the European Union. Other than the present trend of poor demand for loans in the private sector, the interest rate is chiefly related to the expectations of economic agents, both those with surpluses of money, and those in need of finance. Nevertheless, the position of the Serbian economy does not encourage either.

Interest rate swap is a derivative most frequently traded in the world. The swap market is huge, its worth being estimated in trillions of dollars all over the world. In particular, the interest rate swap market is dominated by large financial institutions like banks and hedge funds. The main role of swap banks is intermediation, but they can perform a series of other significant functions.

Swaps are OTC products, arranged and implemented outside the stock exchange. Understanding the OTC market of interest rate swaps facilitates a deeper understanding of the capital market largely consisting of the bond market. It also helps us understand the ways in which companies whose shares we own manage interest rate risk, and ways in which banks generate a large section of their revenues. The usage of interest rate swaps enables cheaper financing to banks and their clients, hedging them against the negative effects of interest rate fluctuations, regardless of whether they are debtors or investors (Cuthberston, 2001). Thus, the enormous size of swap markets, granting protection from interest rate risk, should not come as a surprise.

The tendency of increased reliance on such creations of financial engineering in developed countries is justified by their simple implementation, flexibility, low transaction costs and realistic possibilities for interest rate risk reduction or neutralization.

The objective of this paper is to elaborate on the rules of interest rate swaps usage and their accounting treatment. The theory discussed in this paper is supported by practical examples with a view to providing a detailed insight into this subject matter and the challenges faced in this respect.

\section{Interest Rate Swap Mechanism in Practice}

In the field of derivatives, a popular form of swaps is the interest rate swap, i.e. a swap of one set of interest rates for another. There are many different types of interest rate swaps. Nevertheless, the largest number of swap transactions relates to a very simple product known as generic or plain vanilla swap, which implies a swap of fixed interest rate payments for variable interest rate payments based on 
može da počne bilo kog datuma u budućnosti. Kada postignu dogovor o kamatnom svopu banka i kompanija zapravo trguju varijabilnom i fiksnom kamatnom stopom. Varijabilna kamatna stopa se za mnoge ugovore o kamatnom svopu određuje prema Liboru ili Euriboru. Fiksna kamatna stopa je ovisna o kretanju dugoročnih kamatnih stopa nerizičnih investicija, vrste varijabilne kamatne stope, dužine perioda kamatnog svopa i rasporeda amortizacije kamatnog svopa.

Kamatni svopovi su odvojeni proizvodi koji nisu direktno povezani sa originalnim finansijskim instrumentom (kredit ili investicija) kao štićenom stavkom. Njihov cilj je, pre svega, obezbeđenje stabilnosti plaćanja kamate. Na taj način stranke mogu da drže pod kontrolom svoje buduće troškove kamata i u biznis planovima iskažu potencijalne koristi od stabilne baze troškova.

\section{Funkcija posrednika u kamatnom svopu}

Uloga svop posrednika je povezivanje potencijalnih učesnika u svop transakcijama i pružanje pomoći za postizanje sporazuma između njih. Često su učesnici svopa jedni drugima nepoznati, čak i nakon postizanja dogovora oni ne kontaktiraju jer se svaka stranka bavi samo svop bankom koja uzima naknadu ili procenat od svop novčanih tokova zavisno od detalja ugovora.

Stranke, učesnice svopa, često poštuju anonimnost iz konkurentskih razloga. Grubo rečeno, stranke ne žele da konkurenti znaju na koji način vode svoje biznise, neutrališu svoje rizike i pribavljaju kapital. Svi ti detalji i informacije ako se otkriju učesnicima na tržištu mogu da imaju negativan uticaj na stranke u svopu. Na primer, hedž fondovi mogu da formiraju stavove o cenama na odeređenom tržištu i da se uključe u velike svop transakcije i ostvare koristi od tih informacija. Istovremeno, bi želeli da spreče isključivanje ostalih jer to može da utiče na cene na tržištu koje svop pokriva.

Svop posrednik često upravlja svim novčanim tokovima po svopu, skuplja i prosleđuje periodična plaćanja između stranaka i time čuva anonimnost. Često, posrednik vrši kreditne usluge uključujući i procenu kreditne sposobnosti stranaka pa čak i garantuje blagovremeno plaćanje novčanih tokova.
Pouzdanost posrednika može da doprinese povećanju vrednosti imovine učesnika u svopu zbog specijalizovanih znanja koje posredovanje donosi. Jaka pregovaračka pozicija posrednika može doneti korist svop stranakama kroz najpovoljniji dogovor i sa najmanjim rizikom. Dobro uspostavljeno posredovanje omogućuje učesnicima svopa novi pristup određenom tržištu koji bi na drugi način bio teško ostvariv.

\section{Motivacioni faktori za korišćenje kamatnih svopova}

Postoje dva razloga zbog kojih ekonomski subjekti žele da se uključe u kamatne svop transakcije:

1. Komercijalni motivi - ekonomski subjekti koji će ostvariti potencijalne koristi od kamatnih svopova su svakako banke i hedž fondovi. Banke moraju da obezbede izvore prihoda da bi odgovorile svojim obavezama. Na primer, ako banka plaća varijabilnu kamatnu stopu na svoje obaveze a prima fiksnu kamatnu stopu na plasirane kredite može da se suoči sa značajnim rizicima ako se varijabilne kamatne stope značajno povećaju. $U$ tom slučaju, može da se zaštiti od kamatnog rizika zamenom fiksne kamatne stope koju prima po osnovu datih kredita za varijabilnu koja je viša od stope koju plaća na svoje obaveze. Efektivno, banka će ostvariti veće prihode od troškova i time izbeći krizu gotovinskih tokova. Hedž fondovi, oslanjajući se na špekulacije sa minimalnim troškovima ostvaruju potencijalnu korist. Preciznije, špekulativni hedž fond sa velikim iskustvom i velikom preciznošću u predviđanju kretanja kamatnih stopa mogu da naprave ogroman profit ulaskom u kamatne svop transakcije.

2. Komparatione prednosti - neke kompanije sa boljom bonitetnom ocenom mogu da dobiju relativno jeftinije kredite po nižim fiksnim ili varijabilni kamatnim stopama od većine drugih kompanija. To podrazumeva neku vrstu finansijski podsticajnog mehanizma za ulazak u svop i stvaranje potencijalne komparativne prednosti na osnovu "uštede u troškovima". Navedeno je moguće razjasniti na sledećem primeru. Kompanija ima mogućnost zaduživanja $u$ datom trenutku po varijabilnoj kamatnoj stopi od LIBOR + 0,5\% ili po fiksnoj kamatnoj 
a notional principal amount. The interest rate swap is a series of forward contracts on interest rates (Hull, 2007). In effect, it is only net interest payments that get swapped. This means that the party with the higher debt pays the difference in interest rates to the other party.

The interest rate swap is a long-term agreement concluded for the period ranging from three months to fifteen years, and it can commence at any date in the future. Once they reach an agreement on the interest rate swap, the bank and the company actually trade in variable and fixed interest rates. For many interest rate swap contracts, the variable interest rate is defined based on Libor or Euribor. The fixed interest rate depends on the trends in long-term interest rates of risk-free investments, types of variable interest rates, interest rate swap duration, and interest rate swap amortization schedule.

Interest rate swaps are separate products which are not directly related to the underlying financial instrument (loan or investment) as the hedged item. Their purpose is, primarily, to ensure regularity of interest repayment. Thereby, the parties can keep under control their future interest costs and express in their business plans the potential benefits from a stable costs basis.

\section{The Function of Interest Rate Swap Intermediaries}

The role of swap intermediaries is to connect potential participants in swap transactions and to facilitate agreement among them. Swap participants are often unknown to each other; they do not contact each other even after the agreement is reached because each party deals only with the swap bank taking a fee or a commission from the swap cash flow depending on the conditions stipulated by the contract.

The parties participating in a swap transaction often respect the anonymity for competitive reasons. Roughly speaking, the parties do not want their competitors to know in which way they manage their businesses, neutralize their risks and mobilize capital. All these details and information, if disclosed to market participants, may adversely affect the swap participants. For instance, hedge funds may form their opinions about the prices at a specific market and get involved in large swap transactions, gaining benefits from such information. At the same time, they would like to prevent others from getting involved because that could affect the prices at the market covered by the swap.

A swap intermediary typically manages all swap-related cash flows, collects and forwards periodical payments among the parties, thereby preserving their anonymity. Frequently, it is the intermediary who conducts credit services, including the assessment of the parties' creditworthiness, and he even guarantees the timely payment of cash flows. The reliability of intermediaries can contribute to the increased value of assets of swap participants, due to the specialized knowledge that the intermediation brings. A strong negotiating position of the intermediary may bring benefits to the swap parties in the form of the most favorable deal entailing the lowest risk. A well-established negotiation provides the swap participants with fresh access to a certain market that would otherwise be hardly feasible.

\section{Motivational Factors for Using Interest Rate Swaps}

There are two reasons for economic subjects to want to join interest rate swap transactions:

1. Commercial motives - economic entities that enjoy potential benefits from interest rate swaps are certainly banks and hedge funds. Banks must provide sources of income to service their liabilities. For instance, if a bank pays variable interest rate on its liabilities, and receives fixed interest rate on granted loans, it might face considerable risks if variable interest rates substantially increase. In that case, it can hedge itself against interest rate risk by swapping the fixed interest rate it receives in respect of the granted loans with a variable rate higher than the rate the bank pays on its liabilities. In effect, the bank will yield income higher than its costs, thereby avoiding a crisis in its cash flows. Hedge funds achieve potential benefits by relying on speculations at minimum costs. More precisely, a speculative hedge fund with rich experience and high accuracy in predicting interest rate trends may yield 
stopi od $12 \%$. Istovremeno banka se može zaduživati po LIBOR ili po fiksnoj stopi od 10,5\%. Banka će, stoga uzeti kredit po fiksnoj a kompanija po varijabilnoj višoj kamatnoj stopi i zaključiti kamatnu svop transakciju. Ovde je komparativna prednost banke manja fiksna kamatna stopa. Kompanija pristaje da plati banci 11\% fiksnu kamatnu stopu a banka varijabilnu - Libor.
Generalno, kamatni svopovi podrazumevaju dve osnovne vrste rizika: kamatni i kreditni rizik. Stvarno kretanje kamatnih stopa ne podudara se uvek sa predviđanjima. Obveznik fiksne kamatne stope profitira ako kamatne stope rastu i gubi kada kamatne stope padaju - ostaje "okovan" fiksnom kamatnom stopom. Druga vrsta rizika je kreditni rizik kao verovatnoća da će kompanija učesnik u svop transakciji zapasti u poslovne teškoće ili bankrotirati i tako u potpunosti prestati izvršavati svoje obaveze.

Kamatni svop ne podrazumeva dodatne troškove za kompanije ukoliko kredit i njegov prateći svop traju do ugovorenog roka dospeća, međutim, mogu da izazovu dodatne troškove $\mathrm{u}$ situacijama suprotnim od očekivanih:

- $\quad$ kada se kamatne stope nisu povećale nego su prilično pale $\mathrm{i}$

Ovaj primer pokazuje da kompanija ima komparativnu prednost na varijabilnom a banka na fiksnom tržištu, kao i to da varijabilne kamatne stope više nemaju uticaja na kompaniju.

\section{Rizici povezani sa kamatnim svopom}

Svopovi mogu biti koristan aranžman koji donosi prednosti svim učesnicima $u$ transakciji, međutim, oni još uvek nose značajne rizike koje treba uzeti $u$ obzir pre nego što se ugovor potpiše. Ako su uspešno upotrebljeni i prilagođeni specifičnostima poslovanja date kompanije, svopovi u velikoj meri omogućuju izolaciju novčanih tokova od negativnog delovanja kamatnog rizika. Međutim, svopovi su dugoročni instrument za zaštitu od kamatnog rizika, svop transakcije se sklapaju za duže vremenske periode (često i do petnaest godina), stoga nije uvek jednostavno pronaći kreditno sposobne klijente spremne da uđu u svop transakcije. Pošto se uslovi razmene utvrđuju na početku svopa, ti uslovi mogu postati povoljni ili nepovoljni zavisno od smera kretanja cena na finansijskim tržištima.

Kamatni svop je fiksna formacija kako za kupca tako i za prodavca. Nedostatak kamatnog svopa je taj što u slučaju pada kamatnih stopa u budućnosti, kupac kamatnog svopa do isteka svopa plaća fiksnu a višu kamatnu stopu.
- kada stranke pokušavaju da redefinišu ili raskinu kamatni svop pre isteka.

Ako su kamatne stope pale, kamatni svopovi imaju negativne vrednosti. To nije problem ako kamatni svop funkcioniše sve do dospeća, u kom slučaju će njegova vrednost uvek biti nula. Do tog datuma, stranke neće imati neizmirene obaveze plaćanja po kamatnom svopu. Ali, ako je kamatni svop prestao da funkcioniše pre roka ili je pretrpeo izmene imaće negativnu vrednost - kompanija će snositi dodatne troškove. To je razlog zbog kojeg se stranke lako ne odlučuju na raskid ili izmene kamatnog svopa.

U ovakvim situacijama najbitnije je sagledati da li je buduća korist veća od troška otkazivanja ili zaključivanja novog kamatnog svopa. U suprotnom, nema ekonomske opravdanosti da se otkaže već zaključena transakcija.

\section{Računovodstveni tretman kamatnog svopa}

Zaštitanovčanog toka od rizika podrazumeva njegovu zaštitu od izloženosti promeni koja nastaje zbog uticaja rizika povezanog sa priznatim dugom npr. kod budućih plaćanja kamata po kreditu dobijenom po varijabilnoj kamatnoj stopi koji može da utiče na dobitak ili gubitak (IASB Expert Advisory Panel, 2008). Zaštita od rizika pomoću jednog instrumenta 
enormous profit by engaging in interest rate swap transactions.

2. Comparative advantages - some companies with better creditworthiness may get relatively cheaper loans with fixed or variable interest rates lower than for most other companies. This implies some sort of a financially enticing mechanism for entering a swap transaction and generating potential comparative advantage based on "cost cutting". The above can be illustrated by the following example. A company has an opportunity to borrow in the given moment at the variable interest rate LIBOR $+0.5 \%$ or at the fixed interest rate of $12 \%$. At the same time, the bank may borrow either at LIBOR or at the fixed rate of $10.5 \%$. Therefore, the bank will take the loan at the fixed rate, whereas the company will take the loan at the higher variable interest rate, and enter an interest rate swap transaction. The bank's comparative advantage in this case is the lower fixed interest rate. The company agrees to pay the fixed interest rate of $11 \%$ to the bank, and the bank agrees to pay the variable LIBOR rate.

business, swaps to a large degree enable the isolation of cash flows from the adverse effects of interest rate risk. However, swaps are long-term instruments of hedge against interest rate risk, with swap transactions being arranged for longer periods of time (often up to fifteen years), hence it is not always simple to find creditworthy clients willing to enter swap transactions. Given that the swap terms and conditions are determined at the beginning of a swap transaction, these conditions might become favorable or unfavorable depending on the direction in which prices at the financial markets move.

An interest rate swap is a fixed formation both for the buyer and for the seller. A drawback of interest rate swaps is that in case of decreasing interest rates in the future, the buyer of the interest rate swap pays the higher fixed interest rate until the expiry of the swap's maturity.

In general, interest rate swaps imply two basic types of risk: interest rate risk and credit risk. The actual interest rates movements do not always coincide with the projections. The payer of the fixed interest rate profits when interest rates grow, and loses when interest rates decline - i.e. he remains "chained" by the

Table 1. Interest rate swap between the company and the bank

\begin{tabular}{|l|r|l|r|}
\hline \multicolumn{2}{|l|}{ Costs of the company } & \multicolumn{2}{|l|}{ Costs of the bank } \\
\hline $\begin{array}{l}\text { Pays a variable } \\
\text { interest rate }\end{array}$ & LIBOR $+0.5 \%$ & $\begin{array}{l}\text { Pays a fixed } \\
\text { interest rate }\end{array}$ & $10.5 \%$ \\
\hline $\begin{array}{l}\text { Interest rate } \\
\text { swap }\end{array}$ & $\begin{array}{l}\text { Interest rate } \\
\text { swap }\end{array}$ & $11 \%$ \\
\hline Pays & $11 \%$ & Pays & LIBOR \\
\hline Receives & LIBOR & Receives & LIBOR \\
\hline Net costs & $11.5 \%$ & Net costs & LIBOR $-0.5 \%$ \\
\hline Without swap & $12 \%$ & Without swap & $0.5 \%$ \\
\hline Saved & $0.5 \%$ & Saved & \\
\hline
\end{tabular}

fixed interest rate. The second type of risk is credit risk, as a probability that the company participating in the swap transaction will face difficulties in its business, or go bankrupt, and, consequently, stop honoring its liabilities.

An interest rate swap does not imply additional costs for companies if the loan and its accompanying swap last until the originally agreed

This example indicates that a company has comparative advantage at the variable market, whereas a bank has comparative advantage at the fixed market, and also that variable interest rates no longer affect the company.

\section{Risks Related to Interest Rate Swap}

Swaps can be a useful arrangement, beneficial for all participants in the transaction, yet they still entail considerable risks that should be taken into account before signing the agreement. If they are successfully implemented and adjusted to the specificities of the concerned company's maturity, yet, they might incur additional costs in certain unexpected situations:

- When interest rates do not grow, but substantially decline instead;

- When the parties attempt to redefine or terminate the interest rate swap before the expiry of its maturity.

If interest rates decline, interest rate swaps have negative values. This does not pose a problem if the interest rate swap functions until maturity, in which case its value will always equal zero. Until that date, the parties will not have any outstanding payment liabilities in 
zaštite sa svrhom kompenzacije varijabilnosti u fer vrednosti ili gotovinskim tokovima štićene stavke naziva se hedžing. Usklađivanje promene $\mathrm{u}$ fer vrednosti instrumenta za zaštitu i štićene stavke u istom bilansu uspeha naziva se računovodstvo zaštite. Konkretno, računovodstvo zaštite usklađuje dobitak/ gubitak na svopu sa gubitkom/dobitkom na štićenoj stavci.

Karakteristike kamatnog svopa kao hedžing instrumenta su sledeće:

- zaključuje se sa stranim licem čiji nominalni iznos mora da bude jednak glavnici ili nominalnom iznosu štićene stavke;

- njegovo dospeće nije kasnije od dospeća ili namirenja štićene stavke i

- ne može se platiti pre dospeća ili raskinuti ranije.

Najčešći primer upotrebe klasičnog kamatnog svopa je srednje velika kompanija sa slabijim bonitetom koja se želi zadužiti na srednji rok. Kako su troškovi kapitala po fiksnoj kamatnoj stopi previsoki (radi lošeg boniteta), kredit će uzeti po varijabilnoj kamatnoj stopi. Na drugoj strani, svesna je mogućnosti da će kamatne stope u budućnosti porasti i time projekat u koji su sredstva investirana postati neekonomičan. To je razlog da zaključi kamatnu svop transakciju i zameni kamatna plaćanja po varijabilnoj kamatnoj stopi za fiksna. Time je zaštićena od nepovoljnog kretanja kamatnih stopa u budućnosti i svoje troškove finansiranja "zaključala" u zbiru fiksne kamatne stope i kamatnog svopa. Navedeno je moguće razjasniti pomoću sledećeg primera.

$\mathrm{Na}$ dan 31.03.2009. kompanija je uzela dugoročni kredit $\mathrm{u}$ vrednosti 15 miliona eura sa rokom otplate od pet godina po godišnjoj kamatnoj stopi Libor $_{12 \mathrm{~m}}+0,50 \%$. Dakle, rizikuje se porast Libor-a i time povećanje troškova finansiranja. Periodični obračuni kamata se vrše na poslednji dan meseca marta (31.03). Kamate se obračunavaju i na dan bilansiranja u cilju razgraničenja troškova finansiranja na dva poreska perioda i uključivanja kamatnih rashoda u poslovni rezultat tekuće godine.

Prema MRS 39, zaštita mora da se odnosi na konkretan identifikovani i određeni rizik da bi se kvalifikovala za računovodstvo zaštite i u krajnjoj instanci mora uticati na neto dobitak ili gubitak. Uslovi za kvalifikaciju za računovodstvo zaštite su (Accounting Standards Council, 2006):

- unapred određen i dokumentovan hedžing odnos;

- jasno identifikovan rizik od kojeg se štitimo;

- da entitet očekuje da će instrument zaštite biti "visoko efektivan" u kompenzovanju određenog rizika od kojeg se štiti.
Tabela 2. Dokumentaciona osnova hedžinga

\begin{tabular}{|c|c|c|}
\hline \multicolumn{3}{|c|}{ Hedžing instrument } \\
\hline \multicolumn{2}{|c|}{$\begin{array}{l}\text { Naziv hedžing } \\
\text { instrumenta }\end{array}$} & Kamatni svop (plain vanilla) \\
\hline \multicolumn{2}{|c|}{ Opis transakcije } & $\begin{array}{l}\text { Prijem kamata po } \text { LIBOR }_{12 m} \text { i } \\
\text { isplata kamata po fiksnoj stopi }\end{array}$ \\
\hline \multicolumn{2}{|c|}{ Datum ugovora } & 31.03 .2009$. \\
\hline \multicolumn{2}{|c|}{ Datum dospeća } & 31.03 .2014$. \\
\hline \multicolumn{2}{|c|}{ Fiksna kamatna stopa } & $2,01 \%$ \\
\hline \multicolumn{2}{|c|}{ Glavnica } & E 15.000.000 \\
\hline \multicolumn{3}{|c|}{ Štićena stavka } \\
\hline \multicolumn{2}{|c|}{ Trajanje hedžing odnosa } & 31.03.2009 - 31.03.2014. \\
\hline \multirow{3}{*}{$\begin{array}{l}\text { Priznati } \\
\text { dug }\end{array}$} & Opis & Rashodi kamata po kreditu \\
\hline & Kamatna stopa & a Libor $_{12 \mathrm{~m}}+0,50 \%$ \\
\hline & Glavnica & E 15.000.000 \\
\hline \multicolumn{3}{|c|}{ Vrsta rizika } \\
\hline \multicolumn{3}{|r|}{ Kamatni rizik } \\
\hline \multicolumn{3}{|c|}{ Vrsta zaštite } \\
\hline & & $\begin{array}{l}\text { Zaštita novčanog toka } \\
\text { priznatog duga od rizika }\end{array}$ \\
\hline
\end{tabular}

Izvor: Autor

Efektivnost zaštite podrazumeva stepen usaglašavanja kompenzacionih promena $\mathrm{u}$ fer vrednosti ili tokovima gotovine koje se pripisuju riziku od kojeg se štitimo koji se postiže korišćenjem kamatnog svopa kao instrumenta zaštite. Da bi kamatni svop bio verovatno uspešan instrument za zaštitu od rizika, nominalni iznos i glavnica kredita, rokovi dospeća za plaćanje, datumi naknadnog merenja, datumi plaćanja i prijema kamata i glavnice kao i osnovica za merenje kamatne stope moraju biti isti kod svopa i štićene stavke (Accounting Standards Council, 2006). U ovom primeru predviđa se da će efektivnost biti moguće precizno izmeriti s obzirom da instrument zaštite i štićena stavka imaju identične karakteristike.

Ukoliko su ispunjeni uslovi tokom perioda finansijskog izveštavanja, zaštita toka gotovine se računovodstveno obuhvata na sledeći način: 
respect of the interest rate swap. However, if the interest rate swap stopped functioning before maturity or underwent some amendments, it will have a negative value - i.e. the company will suffer additional costs. This is why the parties reluctantly resort to interest rate swap termination or amendments.

In such situations, the most important thing is to consider whether the future benefit is higher than the costs of termination or conclusion of a new interest rate swap. Otherwise, there is no economic justification to terminate the already concluded transaction.

\section{Accounting Treatment of Interest Rate Swap}

Protecting a cash flow against the risk implies its protection from the exposure to changes occurring due to the effects of risk related to recognized debt, for instance in respect of future payments of interest on loans granted at a variable interest rate, which might affect profit or loss (IASB Expert Advisory Panel, 2008). Protection from risk by means of a single hedge instrument with the purpose of offsetting the variability of hedged item fair value or cash flows is referred to as hedging. Adjustment of changes in the fair value of hedging instrument and hedged item within the same balance sheet is called hedge accounting. More precisely, hedge accounting adjusts the profit/loss in respect of the swap transaction with the profit/ loss in respect of the hedged item.

The characteristics of interest rate swap as a hedging instrument are the following:

- It is concluded with a foreign entity in the nominal amount which must be equal to the principal or the hedged item nominal amount;

- Its maturity does not expire later than the hedged item's maturity or settlement; and

- It cannot be paid out or terminated before maturity.
The most frequent example of using a classic interest rate swap is a medium-size company with lower creditworthiness, looking for a medium-term loan. Given that costs of capital at a fixed interest rate are too high (due to the poor creditworthiness), the loan will be taken at a variable interest rate. On the other hand, the company is aware of the possibility that interest rates will grow in the future, thereby rendering the project in which it invested the funds noneconomical. This is the reason to conclude an interest rate swap transaction, swapping its interest payments at a variable interest rate for the fixed ones. Thus, the company becomes hedged against the unfavorable future interest rate trends, "locking" its costs of finance within the sum of the fixed interest rate and the interest rate swap. The above can be further clarified by means of the following example.

As of 31.03.2009, a company took a long-term loan in the amount of EUR 15 million with a fiveyear maturity and annual interest rate Libor $_{12 \mathrm{~m}}$ $+0.50 \%$. Therefore, it is exposed to the risk of growing Libor and a consequent increase of the costs of finance. Periodical interest calculations are made on the last day of March (31.03). The interests are also calculated on the balance sheet day, in order to differentiate between the costs of finance for two fiscal periods, and include interest expenditures into the current year's business result.

According to IAS 39, the hedge must refer to the designated identified risk in order to qualify for hedge accounting, and it must be ultimately affecting the net profit or loss. The conditions for hedge accounting qualification are (Accounting Standards Council, 2006):

- Hedging relationship designated and documented in advance;

- Clearly identified hedged risk;

- The entity expects the hedging instrument to be "highly effective" in offsetting the designated hedged risk. 
- deo dobitka ili gubitka od kamatnog svopa kao instrumenta zaštite za koji je utvrđeno da je efektivna zaštita priznaje se direktno u kapitalu kroz izveštaj o ostalom rezultatu;

- neefektivan deo se iskazuje odmah u neto dobitku ili gubitku.

Faktor rizika je u ovom slučaju $12_{\mathrm{m}}$ Libor za Eur. U cilju procene njegove varijabilnosti potrebno je analizirati njegovo kretanje pet godina unazad.

Tabela 3. Kretanje EUR Libor $12_{\mathrm{m}}$

\begin{tabular}{|l|r|}
\hline EUR Libor $-12 \mathrm{~m}$ & \multicolumn{1}{|c|}{ Average } \\
\hline 2004 & $2,121 \%$ \\
\hline 2005 & $4,033 \%$ \\
\hline 2006 & $2,325 \%$ \\
\hline 2007 & $5,124 \%$ \\
\hline 2008 & $3,089 \%$ \\
\hline
\end{tabular}

Izvor: www.global-rates.com

Da bi procenili izloženost novčanog toka po kreditu riziku proi korak je izračunavanje rizične vrednosti kamatnih rashoda za jednogodišnji period - od momenta sklapanja kamatnog svopa do prvog obračuna i razmene kamatnih plaćanja. To zahteva veliku pažnju, jer kada se napravi pogrešan prvi korak, svaki sledeći korak je pogrešan.

Izračunavanje rizične vrednosti (VaR) pre uspostavljanja hedžing odnosa

\begin{tabular}{|l|r|}
\hline Nominalna vrednost glavnice & $15.000 .000 \mathrm{E}$ \\
\hline Spot kamatna stopa & $1,82563 \%$ \\
\hline Kamata & $273.845 \mathrm{E}$ \\
\hline Dnevna varijabilnost Libor-a & $1,11 \%$ \\
\hline Period izračunavanja VaR-a & 31.03.09-31.03.14. \\
\hline Broj radnih dana & 250 \\
\hline Signifikanca & $95 \%$ \\
\hline Rizična vrednost (VaR) & $79.301 \mathrm{C}$ \\
\hline Učešće u štićenoj stavci & $28,96 \%$ \\
\hline
\end{tabular}

Godišnja varijabilnost $(\sigma)$ Libor $12_{\mathrm{m}}$ za Eur je izračunata na osnovu njegovih dnevnih varijabilnosti $\mathrm{u}$ prethodnih pet godina po formuli: $\sigma_{\text {godišnja }}=\sigma_{\text {periodična }} \sqrt{B P}=1,11 \% \sqrt{250}$ $=0,1755064$

Pri čemu je: BP - broj perioda uzetih u obzir u jednoj godini (250 dana).

Prema opštem obrascu, rzična vrednost se izračunava kao proizvod vrednosti izložene stavke $\left(\mathrm{V}_{\mathrm{IS}}\right)$, varijabilnosti faktora rizika kome je stavka izložena ( $\sigma$ ) i standardne devijacije (S) u skladu sa izabranom signifikancom. $\mathrm{VaR}=\mathrm{V}_{\text {IS }}$ ${ }^{*} \sigma *$ S (Holton, Glyn, 2003).

$\mathrm{VaR}=273.845 \times 0,1755064 \times 1,65=79.301$ eura

Tabela 4. Izračunavanje rizične vrednosti (VaR) nakon uspostavljanja hedžing odnosa

\begin{tabular}{|l|r|r|r|}
\hline & $\begin{array}{c}\text { Plaćanje } \\
\text { kamata na } \\
\text { kredit u C }\end{array}$ & $\begin{array}{c}\text { Prijem } \\
\text { kamata po } \\
\text { svopu u E }\end{array}$ & $\begin{array}{c}\text { Plaćanje } \\
\text { kamata po } \\
\text { svopu u C }\end{array}$ \\
\hline Glavnica & 15.000 .000 & 15.000 .000 & 15.000 .000 \\
\hline Kamatna stopa & $1,82563 \%$ & $1,82563 \%$ & $2,010 \%$ \\
\hline Iznos kamate & -273.845 & 273.845 & -301.500 \\
\hline Neto izloženi iznos: & & -301.500 \\
\hline Dnevna varijabilnost Libor-a & & $1,11 \%$ \\
\hline Kamatna stopa & & $0 \%$ \\
\hline Period izračunavanja VaR-a & & 1 godina \\
\hline Broj radnih dana & & 250 \\
\hline Signifikanca & & $95 \%$ \\
\hline Rizična vrednost & \multicolumn{3}{r}{0} \\
\hline Učešće u štićenoj stavci & & $0 \%$ \\
\hline
\end{tabular}

Izvor: Autor

Kao što tabela 4. pokazuje rizična vrednost (VaR) nakon zaključenja svop transakcije jednaka je nuli. Na određene datume u toku trajanja kamatnog svopa sprovode se odgovarajuća knjiženja. Evidentiranje kamatnih svopova počinje sa bilansnim knjiženjem na dan početka svopa a završava se storniranjem na dan dospeća.

\section{Knjiženje na dan zaključenja svopa}

Priznavanje primljenog kredita

Tabela 5.

(u Eur)

\begin{tabular}{|l|l|c|l|}
\hline $\begin{array}{l}\text { R. } \\
\text { br. }\end{array}$ & Opis & Duguje & Potražuje \\
\hline \multirow{2}{*}{1.} & Tekući (poslovni) račun & 15.000 .000 & \\
\cline { 2 - 4 } & Dugoročni krediti & & 15.000 .000 \\
\hline
\end{tabular}

Izvor: Autor

Fer vrednost je najadekvatnija mera za merenje derivativnih instrumenata (Ramirez, 2008). Kod zaštite novčanog toka priznatog duga od rizika kamatni svop na dan bilansiranja se iskazuje po fer vrednosti (IASB Expert Advisory Panel 2008). Prvi obračun kamata po kreditu i kamatnom svopu vrši se 31.03.2010. Pre toga, vrši se obračun kamata za tekuću 2009. godinu koja se završava 31.12. po Libor $_{12 \mathrm{~m}}$ da bi se rashodi kamata uključili u bilans uspeha tekuće godine. Zatim se vrši naknadno merenje kamatnog svopa da bi se u bilansu stanja iskazala promena fer vrednosti. 
Table 2. Documentation basis of the hedging process

\begin{tabular}{|l|l|}
\hline Hedging instrument & $\begin{array}{l}\text { Interest rate swap (plain } \\
\text { vanilla) }\end{array}$ \\
\hline $\begin{array}{l}\text { Title of hedging } \\
\text { instrument }\end{array}$ & $\begin{array}{l}\text { Reception of interest at } \\
\text { LIBOR }_{12 \mathrm{~m}} \text { and disbursement } \\
\text { of interest at the fixed rate }\end{array}$ \\
\hline Transaction description & 31.03 .2009 \\
\hline Contract date & 31.03 .2014 \\
\hline Maturity expiry date & $2.01 \%$ \\
\hline Fixed interest rate & E 15,000,000 \\
\hline Principal & 31.03 .2009 - 31.03.2014 \\
\hline Hedged item & $\begin{array}{l}\text { Interest expenditures in } \\
\text { respect of the loan }\end{array}$ \\
\hline $\begin{array}{l}\text { Duration of the hedge } \\
\text { relation }\end{array}$ & Libor ${ }_{12 \mathrm{~m}}+0.50 \%$ \\
\hline $\begin{array}{l}\text { Recognized } \\
\text { debt }\end{array}$ & Description $15,000,000$ \\
\cline { 2 - 2 } & Interest rate \\
& Principal \\
\hline Type of risk & Interest rate risk \\
\hline \multicolumn{2}{|l|}{$\begin{array}{l}\text { Hedging the recognized } \\
\text { debt cash flow against the } \\
\text { risk }\end{array}$} \\
\hline
\end{tabular}

Source: Author

Hedge effectiveness implies the offsetting of changes in fair value or cash flows ascribed to the hedged risk achieved by means of interest rate swap as the hedging instrument. In order for an interest rate swap to be a successful hedging instrument, the loan's nominal amount and principal, maturity, additional measurement dates, interest and principal payment and reception dates, along with the basis for interest rate measurement, must be the same for the swap and the hedged item (Accounting Standards Council, 2006). In this example the prediction is that it will be possible to measure the effectiveness given that the hedging instrument and the hedged item possess identical characteristics.

If the relevant conditions during the financial reporting period are met, the cash flow hedging is covered in accounting terms as follows:

- The section of profit or loss in respect of the interest rate swap as the hedging instrument which was determined to have been effective hedge is directly recognized as capital through the report on the remaining result;

- The ineffective section is immediately reported as net profit or loss.

The risk factor in this case is $12_{\mathrm{m}}$ Libor for EUR. In order to assess its variability, we must analyze its movements in the past five years.
Table 3. Movements of EUR Libor $12_{\mathrm{m}}$

\begin{tabular}{|l|r|}
\hline EUR Libor $-12 \mathrm{~m}$ & Average \\
\hline 2004 & $2.121 \%$ \\
\hline 2005 & $4.033 \%$ \\
\hline 2006 & $2.325 \%$ \\
\hline 2007 & $5.124 \%$ \\
\hline 2008 & $3.089 \%$ \\
\hline
\end{tabular}

Izvor: www.global-rates.com

In order to assess the risk exposure of the loan's cash flow, the first step is to calculate the value at risk of interest expenditures for a one-year period - i.e. from the moment the interest rate swap was concluded until the first calculation and swapping of interest payments. This requires a lot of attention, because after the incorrect first step, every following step is incorrect as well.

Calculating value at risk (VaR) before establishing the hedge relation:

\begin{tabular}{|l|r|}
\hline $\begin{array}{l}\text { Nominal value of the } \\
\text { principal }\end{array}$ & $15,000,000 \mathrm{E}$ \\
\hline Spot interest rate & $1.82563 \%$ \\
\hline Interest & $273,845 \mathrm{E}$ \\
\hline Daily variability of Libor & $1.11 \%$ \\
\hline VaR calculation period & $31.03 .09-31.03 .14$ \\
\hline Number of working days & 250 \\
\hline Significance level & $95 \%$ \\
\hline Value at risk (VaR) & $79,301 \mathrm{C}$ \\
\hline Share in the hedged item & $28.96 \%$ \\
\hline
\end{tabular}

The annual variability of $(\sigma)$ Libor $12_{\mathrm{m}}$ for EUR is calculated based on its daily variability in the past five years, according to the following formula: $\sigma_{\text {annual }}=\sigma_{\text {periodical }} \sqrt{B P}=1,11 \% \sqrt{250}=$ 0,1755064 .

Where: BP - is the number of periods taken into consideration in one year (250 days).

According to the general pattern, value at risk is calculated as the multiplication of exposed item's value $\left(\mathrm{V}_{\mathrm{EI}}\right)$, variability of the risk factor to which the item is exposed $(\sigma)$ and standard deviation (S) according to the selected confidence level: $\mathrm{VaR}=\mathrm{V}_{\mathrm{EI}}{ }^{*} \sigma^{*} \mathrm{~S}$ (Holton, Glyn, 2003).

$\mathrm{VaR}=273,845 \times 0.1755064 \times 1.65=79,301 \mathrm{EUR}$ 
Vrednost kamatnog svopa izračunava se kao razlika sadašnje vrednosti novčanih tokova po fiksnim kamatnim stopama i sadašnje vrednosti novčanih tokova po varijabilnim kamatnim stopama. Drugim rečima, cena kamatnog svopa izjednačava sadašnju vrednost plaćanja po fiksnoj kamatnoj stopi sa sadašnjom vrednošću plaćanja po varijabilnoj kamatnoj stopi. Novčani tokovi obveznika fiksne kamatne stope poznati su od početka trajanja svopa do dospeća. Suprotno tome, novčani tokovi obveznika varijabilne kamatne stope u početku nisu poznati jer su uslovljeni visinom tržišne kamatne stope. Uprkos činjenici da je vrednost kamatnog svopa na isteku približna nuli, ta će vrednost biti varijabilna sve do dospeća svopa kao posledica varijabilnosti referentne, odnosno, tržišne kamatne stope (Libby, at. all. 2011.)

Na dan obračuna kamata informacije o nivou kamatnih stopa možemo da dobijemo posredstvom poslovnih banaka ili putem Internet sajtova raznih brokerskih kompanija koje imaju praksu da objavljuju stope sa finansijskih tržišta. Neke od njih su: Internet stranice Reuters http://.reuters.com i SEB Group http://sebgroup.com/en/, kao i http://markets. ft.com. Na tačno određene datume određuje se fer vrednost svopa što će se uraditi tako da se diskontuju procenjeni budući novčani prilivi i odlivi po kamatnom svopu.

Međutim, da bismo ispravno izračunali sadašnju vrednost novčanih tokova neophodno je utvrdti diskontnu stopu za buduće datume na koje se vrši razmena novčanih tokova po svopu. Novčani tokovi se diskontuju pomoću spot kamatne stope poznate na dan obračuna. Jednačine koje su upotrebljene su sledeće:

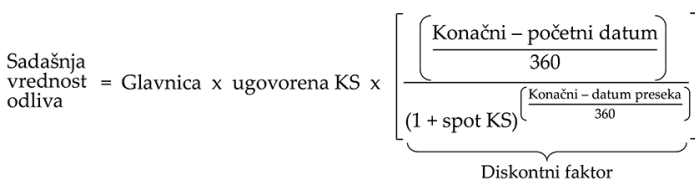

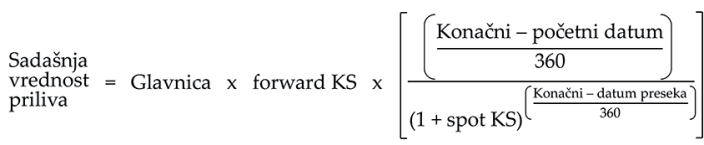

Ceo postupak izračunavanja fer vrednosti kamatnog svopa prezentiran je u nastavku.

\begin{tabular}{|c|c|c|c|c|c|c|}
\hline & & & $\begin{array}{c}\text { * Forward } \\
\text { KS }\end{array}$ & * Spot KS & & \\
\hline Kamatni period & $\begin{array}{l}\text { Nominalni } \\
\text { iznos } \\
\text { glavnice }\end{array}$ & $\begin{array}{c}\text { Fiksna } \\
\text { kamatna } \\
\text { stopa }\end{array}$ & $\begin{array}{c}\text { Terminska } \\
\text { varijabilna } \\
\text { kamatna } \\
\text { stopa }\end{array}$ & $\begin{array}{l}\text { Tržišna } \\
\text { kamatna } \\
\text { stopa }\end{array}$ & $\begin{array}{c}\text { Sadašnja } \\
\text { vrednost } \\
\text { kamatnih } \\
\text { odliva }\end{array}$ & $\begin{array}{c}\text { Sadašnja } \\
\text { vrednost } \\
\text { kamatnih } \\
\text { priliva }\end{array}$ \\
\hline 31.03.2009 - 31.03.2010 & 15.000.000 & $2,01 \%$ & $1,825630 \%$ & $1,77284 \%$ & $296.233,54$ & $269.061,12$ \\
\hline 31.03.2010 - 31.03.2011 & 15.000 .000 & $2,01 \%$ & $2,121255 \%$ & $2,08273 \%$ & $295.331,78$ & $311.678,67$ \\
\hline 31.03.2011 - 31.03.2012 & 15.000 .000 & $2,01 \%$ & $2,573429 \%$ & $2,35947 \%$ & $294.531,09$ & $377.091,93$ \\
\hline 31.03.2012 - 31.03.2013 & 15.000 .000 & $2,01 \%$ & $2,840140 \%$ & $2,58625 \%$ & $293.878,20$ & $415.251,39$ \\
\hline 31.03.2013 - 31.03.2014 & 15.000 .000 & $2,01 \%$ & $2,981583 \%$ & $2,76934 \%$ & $293.353,17$ & $435.152,59$ \\
\hline \multicolumn{5}{|l|}{ Ukupno: } & $-1.473 .327,78$ & $1.808 .235,70$ \\
\hline \multicolumn{5}{|c|}{ Fer vrednost kamatnog svopa $(1.808 .235,70$ - $1.473 .327,78)$} & $=$ & 334.908 \\
\hline
\end{tabular}


Table 4. Calculating value at risk (VaR) after establishing the hedge relation

\begin{tabular}{|c|c|c|c|}
\hline & $\begin{array}{l}\text { Paying } \\
\text { interest on } \\
\text { credit in } E\end{array}$ & $\begin{array}{l}\text { Receiving } \\
\text { interest } \\
\text { within a } \\
\text { swap in } \mathrm{E}\end{array}$ & $\begin{array}{c}\text { Paying } \\
\text { interest } \\
\text { within a } \\
\text { swap in } \mathrm{E}\end{array}$ \\
\hline Principal & $15,000,000$ & $15,000,000$ & $15,000,000$ \\
\hline Interest rate & $1.82563 \%$ & $1.82563 \%$ & $2.010 \%$ \\
\hline $\begin{array}{l}\text { Amount of } \\
\text { interest }\end{array}$ & $-273,845$ & 273,845 & $-301,500$ \\
\hline \multicolumn{2}{|c|}{ Net exposed amount: } & & $-301,500$ \\
\hline \multicolumn{2}{|c|}{ Daily variability of Libor } & & $1.11 \%$ \\
\hline \multicolumn{2}{|c|}{ Interest rate } & & $0 \%$ \\
\hline \multicolumn{2}{|c|}{ VaR calculation period } & & 1 year \\
\hline \multicolumn{2}{|c|}{ Number of working days } & & 250 \\
\hline \multicolumn{2}{|c|}{ Significance level } & & $95 \%$ \\
\hline \multicolumn{2}{|c|}{ Value at risk } & & 0 \\
\hline \multicolumn{2}{|c|}{ Share in the hedged item } & & $0 \%$ \\
\hline
\end{tabular}

Source: Author

As Table 4 indicates, the value at risk (VaR) following the arrangement of a swap transaction equals zero. Relevant book entries are made on specific dates during the course of the interest rate swap. The book-keeping of interest rate swaps begins with the balance sheet entry on the swap commencement date, and ends when the swap is settled on maturity date.

\section{Book-keeping at the swap conclusion date} Recognition of the received loan

Table 5.
\begin{tabular}{|l|l|c|c|}
\hline $\begin{array}{l}\text { Ord. } \\
\text { no. }\end{array}$ & Description & Payable & Receivable \\
\hline \multirow{2}{*}{1.} & $\begin{array}{l}\text { Current (business) } \\
\text { account }\end{array}$ & $15,000,000$ & \\
\cline { 2 - 4 } & Long-ter loan & & $15,000,000$ \\
\hline
\end{tabular}

Source: Author

Fair value is the most adequate measure for derivative instruments measurement (Ramirez, 2008). When it comes to hedging the cash flow of the recognized debt, the interest rate swap on the balance sheet day needs to be reported at fair value (IASB Expert Advisory Panel 2008). The first calculation of interest in respect of the loan and interest rate swap is performed on 31.03.2010. Before that, the interest is calculated for the current year of 2009, ending on 31.12, at Libor $_{12 \mathrm{~m}}$ so that interest expenditures could be included in the current year's profit and loss statement. This is followed by additional interest rate swap measurement in order to report the fair value changes in the balance sheet.

The value of interest rate swap is calculated as a difference between the present value of cash flows at the fixed interest rates and the present value of cash flows at the variable interest rates. In other words, the interest rate swap price makes the present value of payments at the fixed interest rate equal to the present value of payments at the variable interest rate. Cash flows of the fixed interest rate payer are known from the initiation of swap until maturity. As opposed to that, the cash flows of the variable interest rate payer are not known given that they are conditioned by the level of the market interest rate. Despite the fact that the interest rate swap value upon maturity approaches zero, this value will be variable until swap maturity, as a consequence of the variability of the benchmark, i.e. market interest rate (Libby, et al., 2011).

On the interest calculation date, we can obtain the information about the interest rate level by means of commercial banks or on the websites of various broker agencies with the practice of publishing rates from the financial markets. Some of these are: the webpage of Reuters http://.reuters.com; SEB Group http://sebgroup.com/en/; and http://markets. ft.com. On specific dates the swap fair value is determined by discounting the estimated future cash flows and outflows in respect of the interest rate swap.

However, in order to accurately calculate the present value of cash flows, we need to determine the discount rate for future dates on which the swap cash flows are being swapped. Cash flows are being discounted by means of a spot interest rate known on the calculation date. The following formulas are applied:

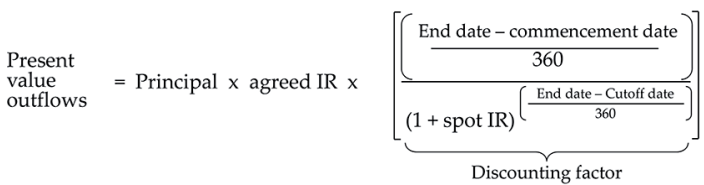

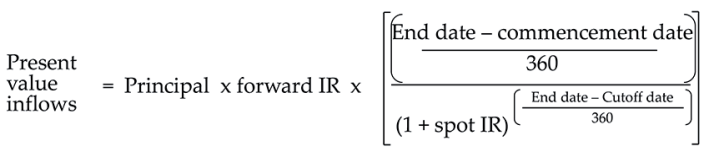

The entire process of calculating the fair value of the interest rate swap is presented below. 
Iz tabele je vidljivo da su najpre izračunate sadašnje vrednosti odliva i priliva od kamatnog svopa za sve buduće periodične obračune po svopu. Varijabilna kamatna stopa na dan 31.03.2009. godine je $12_{\mathrm{m}}$ Libor. Terminska kamatna stopa je kamatna stopa koja se određuje danas za izračunavanje priliva i odliva u budućnosti. Do traženih stopa može se doći posredstvom poslovnih banaka ili putem Internet sajtova raznih brokerskih kompanija. Međutim, treba imati u vidu da se stope na tržištu iz časa $u$ čas menjaju tj. koriste se $u$ datom trenutku.

Za budući periodični obračun 31.03.201031.03.2011. korišćena je dvogodišnja swap kamatna stopa; 31.03.2011-31.03.2012. trogodišnja swap kamatna stopa; 31.03.201231.03.2013. četvorogodišnja swap kamatna stopa i za periodični obračun 31.03.201331.03.2014. petogodišnja swap kamatna stopa. Takođe, terminske varijabilne kamatne stope za buduće periode mogu se izračunati pomoću formule za izračunavanje predviđene kamatne stope (eng. implied forward rate) na osnovu javno objavljenih dugoročnih kamatnih stopa kao ulaznih podataka.

\section{Obračun kamata za 2009. godinu i postupak knjiženja}

LIBOR $_{12 \mathrm{~m}}$ za Eur 31.12.2009. iznosio je 1,21750 a obračunate kamate na taj datum iznose 182.625 eura.

\section{Knjiženje}

Tabela 7.
\begin{tabular}{|c|l|c|r|}
\hline R. br. & Opis & Duguje & Potražuje \\
\hline \multirow{2}{*}{2.} & Rashodi kamata & 182.625 & $\begin{array}{l}\text { Pasivna } \\
\text { vremenska } \\
\text { razgraničenja }\end{array}$ \\
\end{tabular}

Izvor: Autor

Promena fer vrednosti kamatnog svopa iskazuje se $\mathrm{u}$ bilansu stanja. Prilikom ulaska u kamatni svop nije bilo razmene tako da je na početku fer vrednost jednaka nula - nema knjiženja transakcije. Na dan bilansa 31.12.2009. fer vrednost svopa iznosi 334.908 eura.

\section{Knjiženje fer vrednosti kamatnog svopa}

Tabela 8.
\begin{tabular}{|c|l|c|r|}
\hline R. br. & Opis & Duguje & Potražuje \\
\hline \multirow{3}{*}{3.} & Kamatni svop & 334.908 & \\
\cline { 2 - 4 } & $\begin{array}{l}\text { Dobici/gubici } \\
\text { po osnovu } \\
\text { istrumenata } \\
\text { zaštite od rizika } \\
\text { novčanog toka }\end{array}$ & & 334.908 \\
\hline
\end{tabular}

Izvor: Autor

Tako se povećanje ili smanjenje fer vrednosti kamatnog svopa knjiži direktno u kapitalu jer smo se opredelili prema MRSFI da je zaštita uspešna.

Tabela 9. Obračun kamata po kreditu i neto prebijanje kamata po kamatnom svopu 31.03.2010.

\begin{tabular}{|l|r|l|r|}
\hline \multicolumn{2}{|l|}{ Kredit } & \multicolumn{2}{|l|}{ Kamatni svop } \\
\hline $\begin{array}{l}\text { Datum } \\
\text { obračuna }\end{array}$ & 31.03 .2010$. & $\begin{array}{l}\text { Datum } \\
\text { obračuna }\end{array}$ & 31.03 .2010$. \\
\hline Glavnica $^{\mid}$ & 15.000 .000 & Glavnica & 15.000 .000 \\
\hline LIBOR $_{12 \mathrm{~m}}$ & $1,18875 \%$ & LIBOR $_{12 \mathrm{~m}}$ & $1,18875 \%$ \\
\hline $\begin{array}{l}\text { Iznos } \\
\text { kamate }\end{array}$ & 178.313 & $\begin{array}{l}\text { Iznos } \\
\text { kamate }\end{array}$ & 178.313 \\
\hline Marža & $0,50 \%$ & $\begin{array}{l}\text { Fiksna } \\
\text { kamatna } \\
\text { stopa }\end{array}$ & $2,01 \%$ \\
\hline $\begin{array}{l}\text { Iznos } \\
\text { kamate }\end{array}$ & 253.313 & $\begin{array}{l}\text { Iznos } \\
\text { kamate }\end{array}$ & 301.500 \\
\hline Neto plaćanje kamata (301.500-178.313) 123.188 \\
\hline
\end{tabular}

\section{Knjiženje}

Kamatni svopovi koji se koriste u svrhu zaštite vrednuju se naknadno primenom fer metoda.

Tabela 10.
\begin{tabular}{|c|l|c|c|}
\hline & Opis & Duguje & Potražuje \\
\hline \multirow{3}{*}{4.} & Rashodi kamata & 70.688 & $\begin{array}{l}\text { Pasivna vremenska } \\
\text { razgraničenja }\end{array}$ \\
\cline { 2 - 4 } & $\begin{array}{l}\text { Kratkoročne } \\
\text { finansijske obaveze }\end{array}$ & 182.625 & \\
\hline $4 . a$ & Rashodi kamata & 123.188 & 253.313 \\
\hline & $\begin{array}{l}\text { Kratkoročne } \\
\text { finansijske obaveze }\end{array}$ & & 123.188 \\
\hline Izvor: Autor
\end{tabular}


Table 6. Calculating the interest rate swap fair value as of the balance date 31.12.2009

\begin{tabular}{|c|c|c|c|c|c|c|}
\hline & & & $\begin{array}{c}{ }^{*} \text { Forward } \\
\text { KS }\end{array}$ & * Spot KS & & \\
\hline Interest period & $\begin{array}{l}\text { Nominal } \\
\text { amount } \\
\text { of the } \\
\text { principal }\end{array}$ & $\begin{array}{c}\text { Fixed } \\
\text { interest } \\
\text { rate }\end{array}$ & $\begin{array}{c}\text { Forward } \\
\text { variable } \\
\text { interest rate }\end{array}$ & $\begin{array}{c}\text { Market } \\
\text { interest } \\
\text { rate }\end{array}$ & $\begin{array}{c}\text { Present value } \\
\text { of interest } \\
\text { outflows }\end{array}$ & $\begin{array}{c}\text { Present value } \\
\text { of interest } \\
\text { inflows }\end{array}$ \\
\hline 31.03.2009 - 31.03.2010 & $15,000,000$ & $2.01 \%$ & $1.825630 \%$ & $1.77284 \%$ & $296,233.54$ & $269,061.12$ \\
\hline 31.03 .2010 - 31.03.2011 & $15,000,000$ & $2.01 \%$ & $2.121255 \%$ & $2.08273 \%$ & $295,331.78$ & $311,678.67$ \\
\hline 31.03.2011 - 31.03.2012 & $15,000,000$ & $2.01 \%$ & $2.573429 \%$ & $2.35947 \%$ & $294,531.09$ & $377,091.93$ \\
\hline 31.03.2012 - 31.03.2013 & $15,000,000$ & $2.01 \%$ & $2.840140 \%$ & $2.58625 \%$ & $293,878.20$ & $415,251.39$ \\
\hline $31.03 .2013-31.03 .2014$ & $15,000,000$ & $2.01 \%$ & $2.981583 \%$ & $2.76934 \%$ & $293,353.17$ & $435,152.59$ \\
\hline \multicolumn{5}{|l|}{ Total } & $-1,473,327.78$ & $1,808,235.70$ \\
\hline \multicolumn{5}{|c|}{ Fair value of the interest rate swap $(1,808,235.70-1,473,327.78)$} & $=$ & 334,908 \\
\hline
\end{tabular}

The table indicates that the first to be calculated were the present values of interest rate swap inflows and outflows, for all future periodical calculations in respect of the swap. The variable interest rate as of 31.03.2009 was $12_{\mathrm{m}}$ Libor. The forward interest rate is the interest rate designated today for the purpose of calculating inflows and outflows in the future. The required rates can be obtained by means of commercial banks or on the websites of various broker agencies. However, one should bear in mind that the market rates constantly change, and that they should be used in the given moment.

For the future periodical calculation in the period 31.03.2010-31.03.2011, we used the twoyear swap interest rate; in the period 31.03.201131.03.2012, the three-year swap interest rate; in the period 31.03.2012-31.03.2013, the fouryear swap interest rate and for the periodical calculation 31.03.2013-31.03.2014, the five-year swap interest rate. Forward variable interest rates for future periods can also be calculated by means of the formula for implied forward rate calculation, based on publicly available long-term interest rates as input data.

\section{Calculation of interest for 2009 and the book-keeping procedure}

LIBOR $_{12 \mathrm{~m}}$ for EUR on 31.12.2009 amounted to 1.21750 and the calculated interest on that date amounted to 182,625 EUR.
Book-keeping

Table 7.
\begin{tabular}{|c|l|c|c|}
\hline $\begin{array}{l}\text { Ord. } \\
\text { no. }\end{array}$ & Description & Payable & Receivable \\
\hline \multirow{2}{*}{2.} & $\begin{array}{l}\text { Interest } \\
\text { expenditures }\end{array}$ & 182,625 & $\begin{array}{l}\text { Accruals and } \\
\text { deffered income }\end{array}$ \\
\end{tabular}

Source: Author

The change in fair value of the interest rate swap is reflected in the balance sheet. At the moment of concluding the interest rate swap, there was no swapping, hence at the beginning the fair value equaled zero - i.e. there are no transaction entries in the books. On the balance sheet date, i.e. on 31.12.2009, the swap's fair value amounted to EUR 334,908.

\section{Book-keeping the interest rate swap fair value}

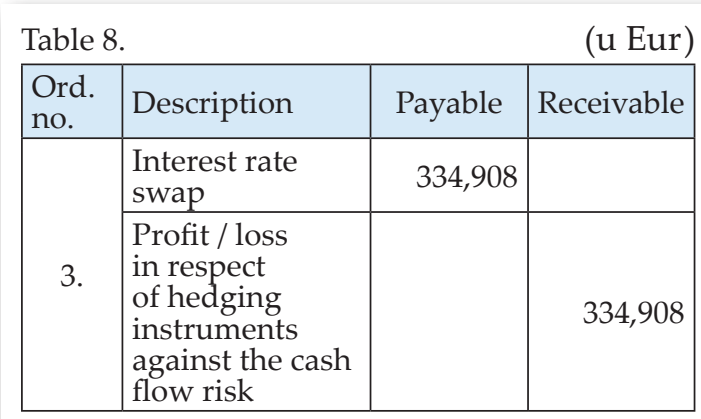

Source: Author 
Neto rashodi kamata po osnovu hedžing odnosa iznose 301.500 eura.

\begin{tabular}{|c|c|c|c|c|c|c|}
\hline & & & $\begin{array}{c}{ }^{*} \text { Forward } \\
\text { KS }\end{array}$ & *Spot KS & & \\
\hline $\begin{array}{l}\text { Kamatni } \\
\text { period }\end{array}$ & $\begin{array}{l}\text { Nominalni } \\
\text { iznos } \\
\text { glavnice }\end{array}$ & $\begin{array}{c}\text { Fiksna } \\
\text { kamatna } \\
\text { stopa }\end{array}$ & $\begin{array}{c}\text { Terminska } \\
\text { varijabilna } \\
\text { kamatna } \\
\text { stopa }\end{array}$ & $\begin{array}{c}\text { Tržišna } \\
\text { kamatna } \\
\text { stopa }\end{array}$ & $\begin{array}{c}\text { Sadašnja } \\
\text { vrednost } \\
\text { kamatnih } \\
\text { odliva }\end{array}$ & $\begin{array}{c}\text { Sadašnja } \\
\text { vrednost } \\
\text { kamatnih } \\
\text { priliva }\end{array}$ \\
\hline \multicolumn{7}{|l|}{ 31.03.2009 - 31.03.2010. } \\
\hline 31.03 .2010 - 31.03.2011. & 15.000 .000 & $2,01 \%$ & $1,18880 \%$ & $1,18880 \%$ & $-297.948,10$ & $176.219,25$ \\
\hline 31.03.2011 - 01.03.2012. & 15.000 .000 & $2,01 \%$ & $2,15023 \%$ & $1,20518 \%$ & $-297.899,75$ & $318.683,73$ \\
\hline 31.03.2012 - 01.03.2013. & 15.000 .000 & $2,01 \%$ & $2,28460 \%$ & $1,89842 \%$ & $-295.867,44$ & $336.288,48$ \\
\hline $31.03 .2013-31.03 .2014$. & 15.000 .000 & $2,01 \%$ & $2,58922 \%$ & $2,29905 \%$ & $-294.705,54$ & $379.630,23$ \\
\hline \multicolumn{5}{|l|}{ Ukupno: } & $-1.186 .420,82$ & $1.210 .821,69$ \\
\hline \multicolumn{5}{|c|}{ Fer vrednost kamatnog svopa $(1.210 .821,69$ - $1.186 .420,82)$} & & $24.400,87$ \\
\hline
\end{tabular}

Fer vrednost kamatnog svopa je manja za 310.507 eura u odnosu na 31.12.2009.

Fer vrednost 31.12.2009. 334.908

Fer vrednost 31.03.2014. 24.401

Promena: 310.507

$\mathrm{Na}$ kraju prve godine kamatna stopa je pala. Prema tome, gubitak na svopu se odmah priznaje - ali dobitak koji to kompenzuje (nije još priznat) zbog toga što se plaća niža varijabilna kamatna stopa u budućnosti. U slučaju pada kamatnih stopa u budućnosti, kupac kamatnog svopa do isteka svopa plaća fiksnu a višu kamatnu stopu. Pri sklapanju kamatne svop transakcije tržišna kamatna stopa je iznosila 1,825630\%. Uz takvu kamatnu stopu je ugovoreno plaćanje fiksnih kamata po svopu od 2,01\%. Na dan bilansa tržišna kamatna stopa je iznosila 1,77284\%, a na dan 31.03.2010. $1,1888 \%$. Zbog pada tržišne kamatne stope kamatni odlivi po svopu obračunati po fiksnoj kamatnoj stopi premašuju kamatne prilive po svopu obračunate po varijabilnoj kamatnoj stopi.

U stvarnosti, kretanje kamatnih stopa ne podudara se uvek sa predviđanjima (grafik 1).
Grafik 1. Kretanje Eur Libor $12_{\mathrm{m}}$ (2004-2008)

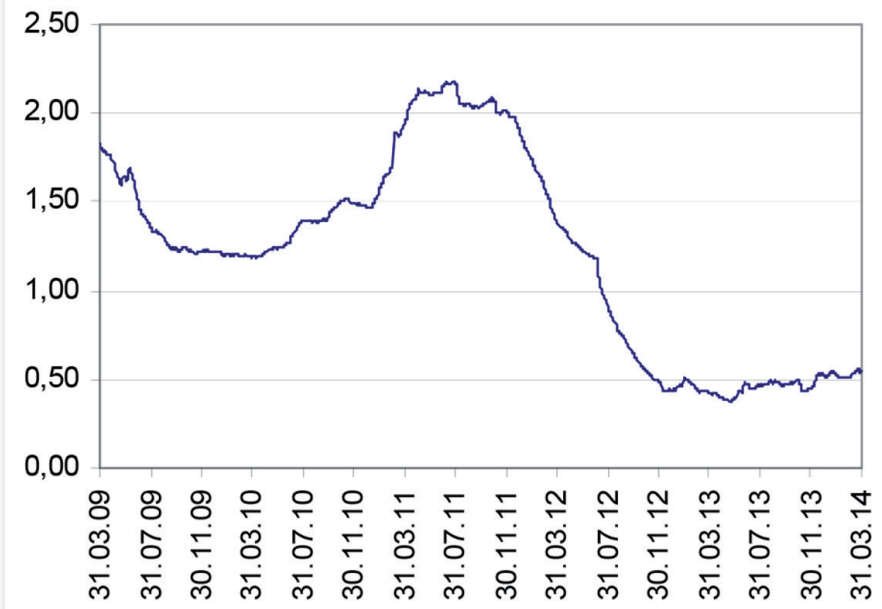

Izvor: ICE Benchmark Administration Limited (IBA)

Knjiženje priznavanja fer vrednosti svopa

Tabela 12.
\begin{tabular}{|c|l|c|c|}
\hline $\begin{array}{l}\text { R. } \\
\text { br. }\end{array}$ & Opis & Duguje & Potražuje \\
\hline & $\begin{array}{l}\text { Dobici/gubici po } \\
\text { Osnovu istrumenata } \\
\text { zaštite od rizika } \\
\text { novčanog toka }\end{array}$ & 310.507 & \\
\cline { 2 - 4 } & Kamatni svop & & 310.507 \\
\hline
\end{tabular}

Izvor: Autor 
Thus, the growth or decline in the fair value of the interest rate swap gets booked directly in capital, because, pursuant to IFRS, we opted for a successful hedge.

Table 9. Calculation of loan interests and net interest settlement in an interest rate swap as of 31.03.2010

\begin{tabular}{|l|r|l|r|}
\hline \multicolumn{2}{|l|}{ Loan } & \multicolumn{2}{|l|}{ Interest rate swap } \\
\hline $\begin{array}{l}\text { Calculation } \\
\text { date }\end{array}$ & 31.03 .2010 & $\begin{array}{l}\text { Calculation } \\
\text { date }\end{array}$ & 31.03 .2010 \\
\hline Principal & $15,000,000$ & Principal & $15,000,000$ \\
\hline LIBOR $_{12 \mathrm{~m}}$ & $1.18875 \%$ & LIBOR $_{12 \mathrm{~m}}$ & $1.18875 \%$ \\
\hline $\begin{array}{l}\text { Amount of } \\
\text { interest }\end{array}$ & 178,313 & $\begin{array}{l}\text { Amount of } \\
\text { interest }\end{array}$ & 178,313 \\
\hline Margin & $0.50 \%$ & $\begin{array}{l}\text { Fixed } \\
\text { interest } \\
\text { rate }\end{array}$ & $2.01 \%$ \\
\hline $\begin{array}{l}\text { Amount of } \\
\text { interest }\end{array}$ & 253,313 & $\begin{array}{l}\text { Amount of } \\
\text { interest }\end{array}$ & 301,500 \\
\hline \multicolumn{3}{|l|}{ Neto plaćanje kamata (301.500-178.313) 123.188} \\
\hline
\end{tabular}

\section{Book-keeping}

Interest rate swaps used for the purpose of hedging are valued additionally by means of the fair value method.

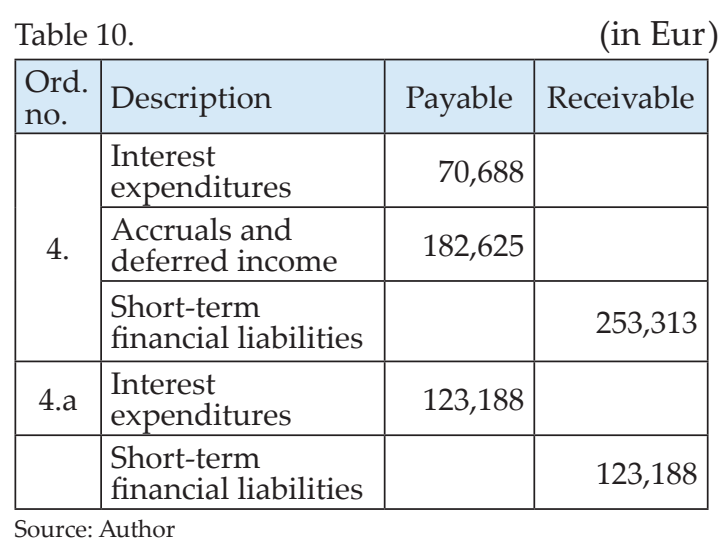

Net interest expenditures in respect of the hedge relation amount to EUR 301,500.

Table 11. Additional interest rate swap measurement as of 31.03.2010

*Forward IR *Spot IR

\begin{tabular}{|c|c|c|c|c|c|c|}
\hline Interest period & $\begin{array}{c}\text { Nominal } \\
\text { amount of } \\
\text { principal }\end{array}$ & $\begin{array}{c}\text { Fixed } \\
\text { interest } \\
\text { rate }\end{array}$ & $\begin{array}{c}\text { Forward } \\
\text { variable } \\
\text { interest rate }\end{array}$ & $\begin{array}{c}\text { Market } \\
\text { interest } \\
\text { rate }\end{array}$ & $\begin{array}{c}\text { Present value } \\
\text { of interest } \\
\text { outflows }\end{array}$ & $\begin{array}{c}\text { Present value } \\
\text { of interest } \\
\text { inflows }\end{array}$ \\
\hline \multicolumn{7}{|l|}{$31.03 .2009-31.03 .2010$} \\
\hline 31.03.2010 - 31.03.2011 & $15,000,000$ & $2.01 \%$ & $1.18880 \%$ & $1.18880 \%$ & $-297,948.10$ & $176,219.25$ \\
\hline $31.03 .2011-01.03 .2012$ & $15,000,000$ & $2.01 \%$ & $2.15023 \%$ & $1.20518 \%$ & $-297,899.75$ & $318,683.73$ \\
\hline $31.03 .2012-01.03 .2013$ & $15,000,000$ & $2.01 \%$ & $2.28460 \%$ & $1.89842 \%$ & $-295,867.44$ & $336,288.48$ \\
\hline $31.03 .2013-31.03 .2014$ & $15,000,000$ & $2.01 \%$ & $2.58922 \%$ & $2.29905 \%$ & $-294,705.54$ & $379,630.23$ \\
\hline \multicolumn{5}{|l|}{ Total: } & $-1,186,420.82$ & $1,210,821.69$ \\
\hline \multicolumn{5}{|c|}{ Fair value of the interest rate $\operatorname{swap}(1,210,821.69-1,186,420.82)$} & & $24,400.87$ \\
\hline
\end{tabular}


Konačno, preostalo je proknjižiti uplate dospelih kamatnih obaveza prema banci po kreditu (6) i neto plaćanje po kamatnom svopu prema banci sa kojom je zaključena kamatna svop transakcija (6a).

\begin{tabular}{l} 
Tabela 13. \\
\begin{tabular}{|c|l|c|c|}
\hline $\begin{array}{l}\text { R. } \\
\text { br. }\end{array}$ & Opis & Duguje & Potražuje \\
\hline 6. & $\begin{array}{l}\text { Kratkoročne } \\
\text { finansijske obaveze }\end{array}$ & 253.313 & \\
\hline & $\begin{array}{l}\text { Tekući (poslovni) } \\
\text { račun }\end{array}$ & & 253.313 \\
\hline & $\begin{array}{l}\text { Kratkoročne } \\
\text { finansijske obaveze }\end{array}$ & 123.188 & \\
\cline { 2 - 4 } $6 . a$ & $\begin{array}{l}\text { Tekući (poslovni) } \\
\text { račun }\end{array}$ & & 123.188 \\
\hline
\end{tabular} \\
Izvor: Autor \\
\hline
\end{tabular}

Ovaj primer pokazuje da je novčani tok uspešno zaštićen od kamatnog rizika uz obezbeđenje stabilnosti plaćanja kamata. Konkretno, dobili smo jasan pregled ukupno plaćenih kamata. Na taj način stranke mogu da drže pod kontrolom svoje buduće troškove kamata i u biznis planovima da iskažu potencijalne koristi od stabilne baze troškova.

\section{Zaključak}

Upotrebna vrednost kamatnih svopova posmatrano kroz prizmu instrumenta za zaštitu od kamatnog rizika je velika. Njihova upotreba u skladu s opštim karakteristikama finansijskih derivata omogućuje efikasnije upravljanje kamatnim rizikom, smanjenje troškova finansiranja i uvećani prinos na uložena sredstva. Ako su uspešno upotrebljeni i prilagođeni specifičnostima poslovanja svop stranaka, svopovi u velikoj meri omogućuju izolaciju novčanih tokova od negativnog delovanja kamatnog rizika.

Bez obzira na opisano, čak i dobro uspostavljeni hedžing odnos stvaraće značajne poteškoće ako politika upravljanja kamatnim rizikom ne predviđa računovodstvo zaštite. Konkretno, upravljanje ovim derivatom može biti zbunjujuće a računovodstveni tretman veoma složen.

Najčešći razlozi nekorišćenja kamatnih svopova su:

- nerazumevanje funkcionisanja kamatnih svopova u upravljanju kamatnim rizikom,

- složenost računovodstvenog evidentiranja i praćenja kamatnih svopova i

- nedovoljna iskustva u poslovima sa finansijskim derivatima.

Takođe, jedna od prepreka za korišćenje ovog vida zaštite je nespremnost kompanija da se informišu, edukuju i upuste $u$ nove transakcije.

Da bi se stvorili uslovi za efikasnu primenu svopova za zaštitu od kamatnog rizika, neophodno je aktivnije pristupiti edukaciji o zaštiti, poznavati računovodstvo zaštite, i svakako znanja i veština u ovoj oblasti kao što su srpsko zakonodavstvo koje proističe iz ISDA okvirnog ugovora koji se koristi za sve svopove. Od razumevanja pravila korišćenja kamatnih svopova zavisiće obim njihove upotrebe $u$ budućnosti, naročito kod malih kompanija.

Osim navedenog, trend korišćenja kamatnih svopova zavisiće i od spremnosti i želje poslovnih banaka da upute svoje klijente $\mathrm{u}$ navedene mogućnosti i pomognu im $\mathrm{u}$ razumevanju pravila njihove primene. 
Fair value of the interest rate swap is lower by 310,507 EUR compared to the position as of 31.12.2009.

Fair value as of 31.12.2009: 334,908

Fair value as of 31.03.2014: 24,401

Difference: 310,507

At the end of the first year, the interest rate dropped. Accordingly, the loss in respect of the swap is immediately recognized, but the offsetting profit is not yet recognized because the lower variable interest rate is to be paid in the future. In case that interest rates decline in the future, the interest rate swap buyer pays the fixed, i.e. higher interest rate until swap maturity. At the moment when the interest rate swap transaction was concluded, the market interest rate amounted to $1.825630 \%$. At this interest rate, the payment of fixed swap interest of $2.01 \%$ was arranged. On the balance day, the market interest rate amounted to $1.77284 \%$, and on 31.03 .2010 it was $1.1888 \%$. Due to the declined market interest rate, the interest outflows in respect of the swap calculated at the fixed interest rate exceeded the interest inflows in respect of the swap calculated at the variable interest rate.

In reality, the movements of interest rates do not always coincide with the projections (Graph 1).

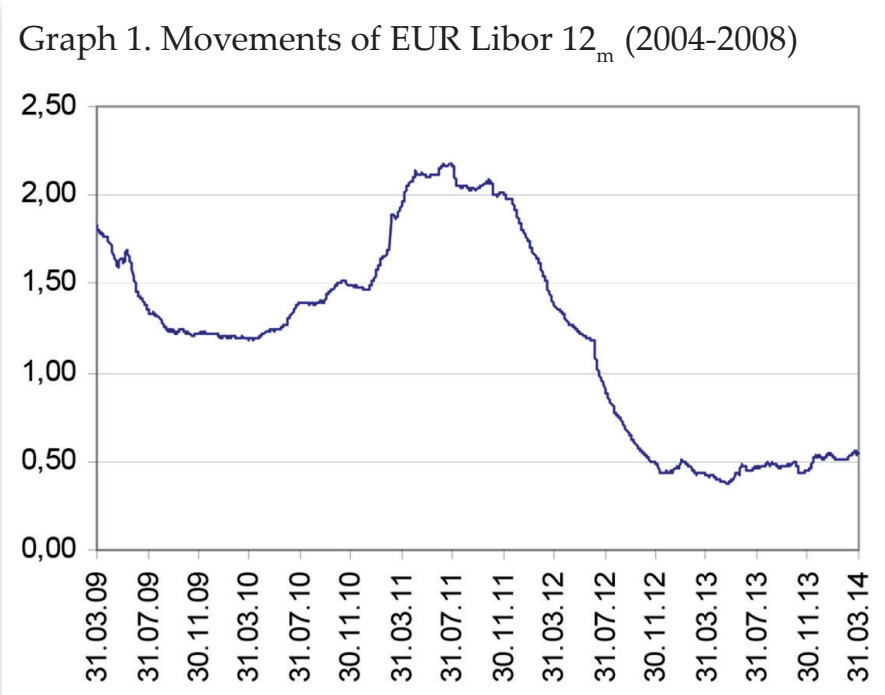

Source: ICE Benchmark Administration Limited (IBA)

Book-keeping the recognition of the swap fair value.

Table 12.
\begin{tabular}{|c|l|c|r|}
\hline $\begin{array}{l}\text { Ord. } \\
\text { no. }\end{array}$ & Description & Payable & Receivable \\
\hline \multirow{2}{*}{5.} & $\begin{array}{l}\text { Profit/Loss in } \\
\text { respect of hedging } \\
\text { instrument against } \\
\text { the cash flow risk }\end{array}$ & 310,507 & \\
\cline { 2 - 4 } & Interest rate swap & & 310,507 \\
\hline
\end{tabular}
Source: Author

Finally, what remains to be booked are the payments of matured interest liabilities towards the bank in respect of the loan (6) and the net payment in respect of the interest rate swap towards the bank with whom the interest rate swap transaction was arranged (6a).

Table 13.
\begin{tabular}{|c|l|c|r|}
\hline $\begin{array}{l}\text { Ord. } \\
\text { no. }\end{array}$ & Description & Payable & Receivable \\
\hline 6. & $\begin{array}{l}\text { Short-term } \\
\text { financial liabilities }\end{array}$ & 253.313 & \\
\hline & $\begin{array}{l}\text { Current (business) } \\
\text { account }\end{array}$ & & 253.313 \\
\hline \multirow{2}{*}{$6 . a$} & $\begin{array}{l}\text { Short-term } \\
\text { financial liabilities }\end{array}$ & 123.188 & \\
\cline { 2 - 4 } & $\begin{array}{l}\text { Current (business) } \\
\text { account }\end{array}$ & & 123.188 \\
\hline
\end{tabular}

Source: Author

This example illustrates that a cash flow is successfully hedged against credit risk and that the stability of interest payments is ensured. In particular, we gained a clear review of total paid interest. This way the parties can keep their future interest costs under control, and present in their business plans the potential benefits from a stable costs basis.

\section{Conclusion}

The use-value of interest rate swaps, viewed from the perspective of interest rate risk hedging instruments, is huge. Their implementation in line with the general characteristics of financial derivatives enables a more efficient interest rate risk management, reduction of costs of finance, and increased revenues on invested funds. If successfully implemented and adjusted to the specificities of the swap parties' business, swaps to a large degree enable the isolation of cash flows from the adverse effects of interest rate risk. 


\section{Literatura / References}

1. Accounting Standards Council. 2006. International Financial Reporting Standard: Financial, Instruments: Recognition and Measurement, Http://www.asc.gov.sg/ frs/attachments/2004/FRS_39_2006.pdf (03.10.2014)

2. Casabona P. Traficanti R. M. 2002. Investment pricing methods - A guide for accounting and financial professionals, New York, John Wiley \& Sons, Inc.

3. Cuthberston K. \& Nitzche, D. 2001. Financial engineering - derivatives and risk management, Chichester [etc.] John Wiley \& Sons, cop.

4. Fraser D. R. Madura J. \& Weigand R. A. 2002. Sources of Bank Interest Rate Risk, The Financial Review 37 (3): 351-367.

5. Glantz Morton 2003. Managing bank risk, London: Academic Press, str. 667.

6. Holton Glyn A. 2003. Value at risk - theory and practice, London: Academic Press

7. Hull J. C. 2007. Risk Management and Financial Institutions, Upper Saddle River, N. J.
8. IASB Expert Advisory Panel 2008. Measuring and Disclosing the Fair Value of Financial Instruments in Markets that are No Longer Active, Draft Document, IASCF, 16. September 2008.

9. Kolb W. R. Overdahl A. J. 2003. Financial Derivatives, $3^{\text {rd }}$ ed. John Wiley \& Sons, Inc. N. J.

10. Libby R. Libby P. A. Short D. G. 2011. Financial Accounting, Boston: McGraw Hill Irwin

11. Overdahl J. A. 2007. Futures, Options, and Swaps, $5^{\text {th }}$ ed., Blackwell Publishing, Oxford 12. Ramirez J. 2008. Accounting for derivatives, Chichester: John Wiley \& Sons Ltd.

13. www.markets.ft.com

14. www.research.stlouisfed.org

15. www.reuters.com

16. www.sebgroup.com

17. www.global-rates.com 
Regardless of the above, even a well established hedging relation will generate substantial difficulties if the interest rate risk management policy does not involve hedge accounting. In particular, this derivative's management might be confusing, and its accounting treatment rather complex.

The most frequent reasons for not using interest rate swaps are the following:

- Lack of knowledge about the functioning of interest rate swaps in the context of interest rate risk management;

- Complexity of the accounting treatment and monitoring of interest rate swaps; and

- Insufficient experience in dealing with financial derivatives.

Another obstacle for using this form of protection is the unwillingness of companies to get informed, educated and involved in new transactions.
In order to generate the conditions for an efficient implementation of swaps providing a hedge against the interest rate risk, it is necessary to approach education on hedging more actively, to get familiar with hedge accounting, and by all means improve the knowledge and skills in this field, including the Serbian legislation based on the ISDA master agreement used for all swaps. The volume of future usage of interest rate swaps, especially by small companies, will depend on the level of understanding the relevant rules.

Moreover, the trend of using interest rate swaps will also depend on the readiness and desire of commercial banks to instruct their clients about the concerned possibilities, helping them understand the rules of their implementation. 